\title{
Endonasal endoscopic reoperation for residual or recurrent craniopharyngiomas
}

\author{
Sivashanmugam Dhandapani, MCh,, Harminder Singh, MD, ${ }^{1,5}$ Hazem M. Negm, MD,1,6 \\ Salomon Cohen, MD, ${ }^{1,7}$ Mark M. Souweidane, MD, ${ }^{1}$ Jeffrey P. Greenfield, MD, PhD,1 \\ Vijay K. Anand, MD, ${ }^{2}$ and Theodore H. Schwartz, MD ${ }^{1-3}$
}

\begin{abstract}
Departments of ${ }^{1}$ Neurosurgery, ${ }^{2}$ Otolaryngology, and ${ }^{3}$ Neuroscience, Weill Cornell Medical College, NewYork-Presbyterian Hospital, New York, New York; " ${ }^{2}$ Department of Neurosurgery, Post Graduate Institute of Medical Education and Research (PGIMER), Chandigarh, India; ${ }^{5}$ Department of Neurosurgery, Stanford University School of Medicine, Stanford, California; ${ }^{6}$ Department of Neurosurgery, Menoufia University, Shebeen El Kom, Egypt; and ${ }^{7}$ Department of Neurosurgery, National Institute of Neurology and Neurosurgery, Mexico City, Mexico
\end{abstract}

OBJECTIVE Craniopharyngiomas can be difficult to remove completely based on their intimate relationship with surrounding visual and endocrine structures. Reoperations are not uncommon but have been associated with higher rates of complications and lower extents of resection. So radiation is often offered as an alternative to reoperation. The endonasal endoscopic transsphenoidal approach has been used in recent years for craniopharyngiomas previously removed with craniotomy. The impact of this approach on reoperations has not been widely investigated.

METHODS The authors reviewed a prospectively acquired database of endonasal endoscopic resections of craniopharyngiomas over 11 years at Weill Cornell Medical College, NewYork-Presbyterian Hospital, performed by the senior authors. Reoperations were separated from first operations. Pre- and postoperative visual and endocrine function, tumor size, body mass index (BMI), quality of life (QOL), extent of resection (EOR), impact of prior radiation, and complications were compared between groups. EOR was divided into gross-total resection (GTR, 100\%), near-total resection (NTR, > $95 \%)$, and subtotal resection (STR, <95\%). Univariate and multivariate analyses were performed.

RESULTS Of the total 57 endonasal surgical procedures, $22(39 \%)$ were reoperations. First-time operations and reoperations did not differ in tumor volume, radiological configuration, or patients' BMI. Hypopituitarism and diabetes insipidus (DI) were more common before reoperations ( $82 \%$ and $55 \%$, respectively) compared with first operations $(60 \%$ and $8.6 \%$, respectively; $p<0.001$ ). For the 46 patients in whom GTR was intended, rates of GTR and GTR+NTR were not significantly different between first operations ( $90 \%$ and $97 \%$, respectively) and reoperations $(80 \%$ and $100 \%$, respectively). For reoperations, prior radiation and larger tumor volume had lower rates of GTR. Vision improved equally in first operations ( $80 \%$ ) compared with reoperations $(73 \%)$. New anterior pituitary deficits were more common in first operations compared with reoperations ( $51 \%$ vs $23 \%$, respectively; $p=0.08$ ), while new DI was more common in reoperations compared with first-time operations ( $80 \%$ vs $47 \%$, respectively; $p=0.08$ ). Nonendocrine complications occurred in 2 (3.6\%) first-time operations and no reoperations. Tumor regrowth occurred in 6 patients (11\%) over a median follow-up of 46 months and was not different between first versus reoperations, but was associated with STR (33\%) compared with GTR+NTR ( $4 \% ; p=0.02)$ and with not receiving radiation after STR ( $67 \%$ vs $22 \% ; p=0.08)$. The overall BMl increased significantly from 28.7 to $34.8 \mathrm{~kg} / \mathrm{m}^{2}$ over 10 years. Six months after surgery, there was a significant improvement in QOL, which was similar between first-time operations and reoperations, and negatively correlated with STR.

CONCLUSIONS Endonasal endoscopic transsphenoidal reoperation results in similar EOR, visual outcome, and improvement in QOL as first-time operations, with no significant increase in complications. EOR is more impacted by tumor volume and prior radiation. Reoperations should be offered to patients with recurrent craniopharyngiomas and may be preferable to radiation in patients in whom GTR or NTR can be achieved.

http://thejns.org/doi/abs/10.3171/2016.1.JNS152238

KEY WORDS craniopharyngioma; endonasal; endoscope; minimally invasive; radiation; recurrence; reoperation; surgery; skull base; oncology

ABBREVIATIONS ASBS-Q = anterior skull base surgery questionnaire; $\mathrm{BMI}=$ body mass index; $\mathrm{DI}=$ diabetes insipidus; $\mathrm{EOR}=$ extent of resection; $\mathrm{GTR}=\mathrm{gross}$-total resection; IQR = interquartile range; NTR = near-total resection; OR = odds ratio; PRL = prolactin; $Q O L$ = quality of life; STR = subtotal resection.

SUBMITTED September 23, 2015. ACCEPTED January 8, 2016.

INCLUDE WHEN CITING Published online May 6, 2016; DOI: 10.3171/2016.1.JNS152238. 
$\mathrm{C}$ RANIOPHARYNGIOMAS are dysembryogenetic epithelial tumors arising from remnants of Rathke's pouch in the craniopharyngeal duct. ${ }^{25,56}$ Although histologically benign, they can be challenging to remove surgically due to their calcified nature and proximity to critical neurovascular structures, such as the hypothalamus, infundibulum, pituitary gland, optic pathway, and circle of Willis. For these reasons, tumors can recur even after apparent gross-total resection (GTR). ${ }^{17,51,56}$ Tumor recurrence is generally managed by either reoperation or radiation, the latter being effective at controlling the growth of solid tumors but less effective at controlling the growth of associated tumor cysts. ${ }^{25,30,51}$ Previous publications have highlighted the higher risk of complications and lower extents of resection (EORs) following reoperation, which has resulted in an increase in the utilization of radiation in the setting of recurrent tumors. ${ }^{48,51,56}$

The endonasal endoscopic transsphenoidal approach has recently been introduced as an alternative to craniotomy for craniopharyngiomas extending up into the suprasellar cistern and third ventricle, even in the absence of sellar involvement. This approach provides a unique view under and behind the chiasm, which some authors feel provides the ability to achieve higher rates of resection with improved visual outcomes. ${ }^{5-7,31-33,38,46}$ How the endonasal approach has impacted outcomes following reoperation and whether the algorithm for selecting patients for reoperation should change is not clear. In the present study, we examined outcomes from endonasal endoscopic reoperations for craniopharyngiomas and compared them with outcomes following first-time operations, including not only the extent of resection but also body mass index (BMI) and quality of life (QOL). We show that the results of reoperations are comparable to those achieved with first-time operations and may be preferable to radiation for tumors amenable to near-total resection (NTR).

\section{Methods}

All patients who underwent endonasal endoscopic extended transsphenoidal surgery for craniopharyngiomas at the Institute for Minimally Invasive Skull Base and Pituitary Surgery at Weill Cornell Medical College, NewYork-Presbyterian Hospital between July 2004 and August 2015 were enrolled in a prospective database with the requisite institutional review board approval. All the patients underwent evaluation by a team comprising specialists from neurosurgery, otolaryngology, ophthalmology, endocrinology, and radiation oncology. We separated those undergoing reoperation from those undergoing a first-time operation. The latter were used as a comparison group for the former. The clinical assessment included demographics, general examination, BMI $\left(\mathrm{kg} / \mathrm{m}^{2}\right)$, visual field, and QOL. The blood samples were evaluated for prolactin (PRL), free thyroxine, fasting morning cortisol, insulin-like growth factor-1, testosterone, estrogen, follicle-stimulating hormone, luteinizing hormone, serum sodium, and urine specific gravity. The radiological evaluation included contrast-enhanced CT and MRI under a neuronavigation protocol. The diameter of tumors was noted in 3 mutually perpendicular planes, and the volume was then calculated using an ellipsoid model " $(\mathrm{ABC}) / 2$ " equation.

\section{Quality of Life}

QOL was assessed using the anterior skull base surgery questionnaire (ASBS-Q), a site-specific QOL instrument that has been validated for use in patients undergoing anterior skull base surgery. ${ }^{1,18,46}$ The ASBS-Q is a 35 -item survey divided into 6 QOL domains: role of performance (6 items), physical function (7 items), vitality (7 items), pain (3 items), specific symptoms (7 items: appetite, taste, smell, appearance, epiphora, nasal secretions, and visual disturbances), and impact on emotions (5 items). Its internal reliability score is 0.8 and the test-retest reliability score is 0.9. Responses are recorded on a 5-item Likert scale, ranging from 1 to 5 points for each item. Subscores are calculated for each domain as well as for the entire instrument. Total scores range from 35 to 175 , with a higher score representing better QOL.

\section{Surgical Procedure}

All surgeries were performed by the senior authors (T.H.S. and V.K.A.) and assisted by pediatric neurosurgeons (M.M.S. and J.P.G.) in children. The approach was usually transsphenoidal, transsellar, and transtuberculumplanum. The surgical steps have been elaborated previously. $7,12,33,36,50$

At the beginning of the procedure, a lumbar drain was placed and $0.25 \mathrm{ml}$ of $10 \%$ fluorescein (AK-FLUOR, Akorn) was injected into $10 \mathrm{ml}$ of $\mathrm{CSF}^{47}$ Patients were positioned in skull pin fixation for intraoperative neuronavigation. The middle turbinates were lateralized. A vascularized nasoseptal flap was raised and set aside in the nasopharynx for subsequent reconstruction. Wide sphenoidotomy and posterior ethmoidectomy were performed. The bone removal included the top of the sella, tuberculum sellae, and parts of the planum sphenoidale as per size of the tumor noted in navigation, and both medial opticocarotid recesses constituted the lateral extent. The superior intercavernous sinus was coagulated and resected along with the diaphragma sella. The tumor was internally debulked and meticulously separated from adjacent neurovascular structures using sharp microdissection. All attempts were made to preserve the infundibulum and superior hypophyseal arteries as long as possible, but these were resected if necessary to achieve a GTR if that was the goal of surgery. In many patients, the roof of the third ventricle and the foramen of Monro could be seen at the end of surgery. The closure was performed with a gasket-seal closure covered with a nasoseptal flap. . $16,37,41,45^{\text {An onlay piece of }}$ autologous fascia lata larger than the bone defect was countersunk with a rigid buttress, such as Medpor (Stryker). The nasoseptal flap was placed over this construct all around and covered with Duraseal (Covidien). A lumbar drain was left in place for approximately 24 hours.

\section{Goals of Surgery}

In most adult cases, the aim of surgery was GTR. In select situations (children with hypothalamic involvement, elderly with comorbidities, intact pituitary function in a 
patient unwilling to accept a postoperative loss of function), patients were planned for intentional subtotal resection (STR), fenestration-decompression of cyst or biopsy, followed by radiation therapy, or observation. The EOR was confirmed by comparison of preoperative and immediate postoperative contrast-enhanced MRI. EOR was categorized as $100 \%$ (GTR), $\geq 95 \%$ and $<100 \%$ (NTR), and $<95 \%$ (STR). Those who had NTR and GTR $\geq$ 95\% were sometimes grouped for statistical purposes as "NTR+GTR."

\section{Outcome and Follow-Up}

Patients were assessed by clinical, laboratory, and radiological evaluation throughout the hospital stay, and at 3 weeks, 6 weeks, 3 months, 6 months, 1 year, and every 2 years subsequently, for any new clinical features, CSF leak, BMI, visual fields, anterior pituitary function, diabetes insipidus (DI), tumor regrowth, and ASBS-Q QOL scores.

\section{Statistical Analysis}

Statistical analysis was performed using SPSS (version 21.0, IBM Corp.). Continuous variables were considered nonparametric as per the Shapiro-Wilk test and were reported as median with interquartile range (IQR). Categorical data were reported as counts and proportions in each group. Univariate analyses of continuous variables across binary categories were compared using the Mann-Whitney U-test and across multiple categories using the Kruskal-Wallis test. The serial changes in continuous variables over time were analyzed by using the Wilcoxon signedrank test (2 samples) or Friedman's 2-way ANOVA ( $\geq 3$ samples). The bivariate relationship between 2 continuous variables was assessed using the Spearman's correlation coefficient. Proportions were compared using the chisquare or Fisher exact test wherever appropriate. Subgroup analyses were performed using the Breslow-Day test of homogeneity of odds ratios (ORs). Two-sided significance tests were used throughout, and the significance level was kept at $p<0.05$. Multivariate analyses on categorical outcomes were conducted using logistic regression, and on continuous outcomes with the general linear model with mandatory significance of the model coefficient set at $<$ 0.05 , after adjusting for various known prognostic factors.

\section{Results}

The overall cohort consisted of a total of 57 endoscopic endonasal extended transsphenoidal surgical procedures, performed for craniopharyngioma in 55 patients since 2004. The median age of patients at surgery was 45 years (range 5-85 years), with 9 children ( $\leq 18$ years) and 19 elderly ( $\geq 60$ years). There were 25 males and 32 females. Of these 57 procedures, 22 (39\%) were reoperations for residual/recurrent tumors, while $35(61 \%)$ were primary first-time operations. Among the 22 reoperations, 9 patients underwent a prior transcranial approach, 4 underwent prior endonasal endoscopic surgery, 1 underwent both prior transcranial as well as endonasal endoscopic approaches, and 8 underwent previous transventricular endoscopic fenestration and biopsy. With the exception of surgeries in 3 patients ( 2 prior endonasal surgeries and 1 prior transventricular biopsy and fenestration), other surgeons performed the initial surgeries. Ten patients had already received radiation (9 conventional fractionated radiotherapy and 1 Cyberknife [Accuray]). Nine patients $(16 \%)$ had undergone prior CSF diversion. Pathology was mostly adamantinomatous $(n=52)$ and papillary $(n=2)$. A few patients were believed to have craniopharyngiomas with xanthogranulomatous change $(n=3)$.

\section{Preoperative Features}

\section{Tumor Size and Radiographic Characteristics}

The median maximum diameter and volume of the tumors were $25 \mathrm{~mm}$ (IQR $18-30 \mathrm{~mm}$ ) and $3.7 \mathrm{ml}$ (IQR $1.9-8.0 \mathrm{ml})$, respectively. The median maximum diameter and volume were $23.5 \mathrm{~mm}$ (IQR $18.5-30 \mathrm{~mm}$ ) and $3.6 \mathrm{ml}$ (IQR 1.5-7.7 ml) for first operations and $26 \mathrm{~mm}$ (IQR 18-29 mm) and 4.1 ml (IQR 2.0-8.4 ml) for reoperations, which was not statistically different $(\mathrm{p}=0.89$ and $\mathrm{p}=0.71$, respectively). First operations and reoperations had a similar distribution of sellar-suprasellar (14 [40\%] and 9 [41\%], respectively), purely suprasellar (5 [14\%] and 2 [9\%], respectively), and purely third ventricular (2 [6\%] and 0 , respectively) tumors. Noncalcified tumors were equally distributed between first operations (4 [11\%]) and reoperations (2[9\%]).

\section{BMI, Visual, and Endocrine Deficits}

Baseline BMI of the study group ranged from 17 to 54 $\mathrm{kg} / \mathrm{m}^{2}$, with a median of $28.7 \mathrm{~kg} / \mathrm{m}^{2}$ (IQR $24.6-33.7 \mathrm{~kg} /$ $\left.\mathrm{m}^{2}\right)$. Obesity $\left(\mathrm{BMI} \geq 30 \mathrm{~kg} / \mathrm{m}^{2}\right)$ was noted in 23 patients. Median baseline BMI for first-time and reoperations was $28.2 \mathrm{~kg} / \mathrm{m}^{2}$ (IQR $24.8-32.4 \mathrm{~kg} / \mathrm{m}^{2}$ ) and $30.6 \mathrm{~kg} / \mathrm{m}^{2}$ (IQR $24.6-34.8 \mathrm{~kg} / \mathrm{m}^{2}$ ), which was not statistically different ( $\mathrm{p}$ $=0.32$ ).

Vision was normal in 8 patients, anterior chiasmal field defects were noted in 12 (unilateral defects in 4, bitemporal defects with additional unilateral central defects in 8), midposterior chiasmal field defects were noted in 32 (bitemporal defects in 31 , homonymous defect in 1), while 5 had nonspecific field abnormalities (Table 1). All 8 patients with normal preoperative vision were in the first-operation group, while all patients in the reoperation group had some sort of visual defect. Children $(3 / 9,33 \%)$ had more anterior chiasmal compression, while adults (30/48, 63\%) had more midposterior chiasmal compression. Anterior chiasmal compression was significantly more frequent among reoperations $(9 / 22,41 \%)$, while most patients undergoing primary endonasal surgery $(21 / 35,60 \%)$ had midposterior chiasmal compression $(\mathrm{p}=0.01)$.

Hypothyroidism was the most common endocrinopathy, followed by hypocortisolemia. Because patients with panhypopituitarism had hypofunction of all hormones, hypothyroidism was present in a total of 35 patients (26 with hypothyroidism +9 with panhypopituitarism), and hypocortisolemia in a total of 24 patients (15 with hypercortisolemia +9 with panhypopituitarism). DI was present in 15 patients. Overall, preexisting endocrinopathy was more common in reoperations than in first-time operations. Anterior pituitary hypofunction was noted more fre- 
TABLE 1. Visual and endocrine defects

\begin{tabular}{|c|c|c|c|c|c|c|c|}
\hline \multirow[b]{2}{*}{ Categories } & \multirow[b]{2}{*}{ Total } & \multicolumn{3}{|c|}{ Age Group } & \multicolumn{3}{|c|}{ Endonasal Surgery } \\
\hline & & $\begin{array}{l}\text { Children } \\
(n=9)\end{array}$ & $\begin{array}{l}\text { Adults } \\
(n=48)\end{array}$ & $p$ Value & $\begin{array}{l}\text { Primary } \\
(n=35)\end{array}$ & $\begin{array}{c}\text { Secondary } \\
(n=22)\end{array}$ & p Value \\
\hline Visual field & & & & 0.1 & & & 0.01 \\
\hline Normal & 8 & 2 & 6 & & 8 & 0 & \\
\hline Anterior chiasmal compression & & & & & 2 & 2 & \\
\hline Unilateral defects & 4 & 2 & 2 & & 1 & 7 & \\
\hline Bitemporal \& unilateral central defects & 8 & 1 & 7 & & & & \\
\hline \multicolumn{8}{|l|}{ Midposterior chiasmal compression } \\
\hline Bitemporal defects & 31 & 2 & 29 & & 20 & 11 & \\
\hline Homonymous defect & 1 & 0 & 1 & & 1 & 0 & \\
\hline Nonspecific & 5 & 2 & 3 & & 3 & 2 & \\
\hline \multicolumn{8}{|l|}{ Endocrine } \\
\hline Stalk effect & & & & 0.67 & & & 0.02 \\
\hline Normal PRL & 45 & 8 & 37 & & 24 & 21 & \\
\hline High PRL & 12 & 1 & 11 & & 11 & 1 & \\
\hline Posterior pituitary & & & & 0.69 & & & $<0.001$ \\
\hline No DI & 42 & 6 & 36 & & 32 & 10 & \\
\hline Prior DI & 15 & 3 & 12 & & 3 & 12 & \\
\hline Anterior pituitary & & & & 0.24 & & & $<0.001$ \\
\hline No hypofunction & 18 & 3 & 15 & & 14 & 4 & \\
\hline Hypothyroid & 10 & 1 & 9 & & 10 & 0 & \\
\hline Hypothyroid, hypocortisol & 15 & 2 & 13 & & 6 & 9 & \\
\hline Hypothyroid, growth hormone deficiency & 1 & 1 & 0 & & 1 & 0 & \\
\hline Hypogonad & 4 & 0 & 4 & & 4 & 0 & \\
\hline Panhypopituitarism & 9 & 2 & 7 & & 0 & 9 & \\
\hline
\end{tabular}

quently in patients with residual/recurrent tumors $(18 / 22$, $82 \%)$, compared with those without prior surgery $(21 / 35$, $60 \%$ ), and DI was significantly more common in residual/ recurrent cases $(12 / 22,55 \%)$ than in primary cases $(3 / 35$, $9 \% ; \mathrm{p}<0.001)$. Prior panhypopituitarism was noted only among residual/recurrent cases (9/22, 41\%; $\mathrm{p}<0.001)$. Twelve patients had preoperative hyperprolactinemia indicating the stalk effect, which was more common in first operations $(11 / 35,31 \%)$ compared with reoperations $(1 / 22$, $5 \% ; \mathrm{p}=0.02)$ likely because of superimposed anterior $\mathrm{pi-}$ tuitary hypofunction among the reoperations (Table 1).

\section{Extent of Resection}

Of the 57 procedures, GTR was planned in 46 cases (Table 2). STR was intended in 5 children with extensive hypothalamic involvement and 4 elderly patients with multiple comorbidities. A cystic tumor arising from the infundibulum with intact pituitary function in 1 adult and a cystic recurrence following radiation in 1 elderly patient were intended for biopsy and fenestration. Among the 46 patients intended for GTR, it was achieved in $40(87 \%)$ patients, while $5(11 \%)$ had NTR, and in $1(2 \%)$ patient with intact pituitary function an on-table decision was made to restrict treatment to STR. Among the 46 intended for GTR, there was no difference in GTR rates for first operations $(28 / 31,90 \%)$, compared with reoperations
$(12 / 15,80 \%)$. First operations and reoperations resulted in NTR in 2/31 (7\%) and 3/15 (20\%), respectively. There was only 1 STR in a first-time operation. Hence, the rate of GTR+NTR was $97 \%$ for first operations and $100 \%$ for reoperations, whenever intended.

Prior radiation, on the other hand, appeared to have a more significant impact on the overall EOR. For the whole cohort, not just those undergoing GTR, patients with prior radiation had a significantly lower rate of GTR+NTR $(5 / 10,50 \%)$ compared with those without prior radiation $(40 / 47,85 \%$; $p=0.03)$. For the 22 patients undergoing reoperation, GTR+NTR was achieved in only $5 / 10(50 \%)$ patients who underwent radiation compared with $10 / 12$ $(83 \%)$ patients who did not undergo radiation $(\mathrm{p}=0.17)$.

Tumor volume also predicted EOR. The maximum diameter and volume of tumors were significantly lower (median $23 \mathrm{~mm}$ [IQR 16-28 mm] and 3.5 $\mathrm{ml}$ [IQR 1.5-7.7 ml], respectively) among those with GTR, compared with those with NTR or STR (median $29 \mathrm{~mm}$ [IQR 20-32 mm] and $4.9 \mathrm{ml}$ [IQR 2.7-13.5 ml], respectively; $\mathrm{p}=0.04$; Fig. 1).

\section{Outcome}

Visual and Endocrine Outcome

The median follow-up duration was 46 months (IQR 23-89 months). Visual outcomes were similar in first operations and reoperations. Ten patients with first opera- 
TABLE 2. Extent of resection in relation to various factors*

\begin{tabular}{|c|c|c|c|c|c|}
\hline Variable & Total & GTR $(\%)$ & $\begin{array}{l}\text { NTR } \\
(\%)\end{array}$ & $\begin{array}{l}\text { STR } \\
(\%)\end{array}$ & $\begin{array}{c}\mathrm{p} \\
\text { Value }\end{array}$ \\
\hline No. & 46 & $40(87)$ & $5(11)$ & $1(2)$ & \\
\hline Age (yrs) & & & & & 0.35 \\
\hline$\leq 18$ & 4 & $4(100)$ & 0 & 0 & \\
\hline $19-59$ & 28 & $22(79)$ & $5(18)$ & $1(4)$ & \\
\hline$\geq 60$ & 14 & $14(100)$ & 0 & 0 & \\
\hline Sex & & & & & 0.31 \\
\hline M & 18 & $16(89)$ & $1(6)$ & $1(6)$ & \\
\hline $\mathrm{F}$ & 28 & $24(86)$ & $4(14)$ & 0 & \\
\hline Reop & & & & & 0.31 \\
\hline No & 31 & $28(90)$ & $2(7)$ & $1(3)$ & \\
\hline Yes & 15 & $12(80)$ & $3(20)$ & 0 & \\
\hline Previous transsphenoidal op & & & & & 0.62 \\
\hline No & 42 & $37(88)$ & $4(10)$ & $1(2)$ & \\
\hline Yes & 4 & $3(75)$ & $1(25)$ & 0 & \\
\hline Previous radiation & & & & & 0.66 \\
\hline No & 41 & $35(85)$ & $5(12)$ & $1(2)$ & \\
\hline Yes & 5 & $5(100)$ & 0 & 0 & \\
\hline Obesity & & & & & 0.45 \\
\hline No & 28 & $25(89)$ & $3(11)$ & 0 & \\
\hline Yes & 18 & $15(53)$ & $2(11)$ & $1(6)$ & \\
\hline Field defects & & & & & 0.54 \\
\hline No & 7 & $7(100)$ & 0 & 0 & \\
\hline Yes & 39 & $33(85)$ & $5(13)$ & $1(3)$ & \\
\hline $\begin{array}{l}\text { Prior anterior pituitary hypo- } \\
\text { function }\end{array}$ & & & & & 0.74 \\
\hline No & 15 & $13(87)$ & $2(13)$ & 0 & \\
\hline Yes & 31 & $27(87)$ & $3(10)$ & $1(3)$ & \\
\hline Prior DI & & & & & 0.78 \\
\hline No & 34 & $29(85)$ & $4(12)$ & $1(3)$ & \\
\hline Yes & 12 & $11(92)$ & $1(8)$ & 0 & \\
\hline Serum PRL & & & & & 0.86 \\
\hline Normal & 36 & $31(86)$ & $4(11)$ & $1(3)$ & \\
\hline High & 10 & $9(90)$ & $1(10)$ & 0 & \\
\hline Hydrocephalus & & & & & 0.74 \\
\hline No & 41 & $36(88)$ & $4(10)$ & $1(2)$ & \\
\hline Yes & 5 & $4(80)$ & $1(20)$ & 0 & \\
\hline Third ventricle involvement & & & & & 0.74 \\
\hline No & 17 & $15(88)$ & $2(12)$ & 0 & \\
\hline Yes & 29 & $25(86)$ & $3(10)$ & $1(3)$ & \\
\hline Retroinfundibular extension & & & & & 0.43 \\
\hline No & 9 & $7(78)$ & $2(22)$ & 0 & \\
\hline Yes & 37 & $33(89)$ & $3(8)$ & $1(3)$ & \\
\hline
\end{tabular}

* Of 46 cases intended for GTR.

tions had normal vision preoperatively, and none of these deteriorated. For the remainder, with preoperative visual deficits of some type, vision improved in 20/25 (80\%) of first operations and 16/22 (73\%) of reoperations. The remainder of the patients had unchanged vision (including those with normal preoperative vision) except for 1 patient who had transient deterioration after a first operation (Table 3). Radiation also did not significantly impact visual outcome. Among those with visual deficits, 13/19 (68\%) of patients who underwent radiation, compared with 23/28 (82\%) patients who did not, experienced visual improvement $(\mathrm{p}=0.31)$. Among those with some anterior pituitary function, additional hypofunction occurred in 18/35 (51\%) first operations compared with 3/13 (23\%) reoperations (p $=0.08$ ). However, as already stated, more of the reoperations already had anterior pituitary hypofunction than the first-time operations. Among patients without prior DI, new DI occurred in 15/32 (47\%) first operations compared with $8 / 10(80 \%)$ reoperations $(p=0.08)$.

\section{Complications}

The complication rate was $3.6 \%$ in first operations and $0 \%$ in reoperations. There was $1 \mathrm{CSF}$ leak that required repair $(1.8 \%)$ and 1 intracranial infection (1.8\%); both of these occurred in first-time operations. There was no perioperative mortality. One patient had immediate subjective visual worsening, and underwent revision of gasket seal closure, on the suspicion of compression of the optic pathway. The patient's vision improved with an elevation in blood pressure.

\section{Further Management and Tumor Regrowth}

Of the 40 patients in whom GTR was achieved, tumor regrowth occurred in only 1 (3\%), or $4 \%$ of 28 first GTR operations and $0 \%$ of reoperations. Of the 5 patients who did not have GTR or elective radiation, tumor regrowth occurred in $3(60 \%)$, or $50 \%$ of the first operations and $100 \%$ of the reoperations. Of the 12 patients who did not have GTR but had elective radiation, tumor regrowth occurred in $2(17 \%)$, or $0 \%$ of the first operations and $22 \%$ of the reoperations.

For all patients, tumor regrowth occurred in 14\% (3/22) following reoperations, and 9\% (3/35) following first operations $(\mathrm{p}=0.67)$. Following reoperations, tumor regrowth was noted in $14 \%(1 / 7)$ who did not receive radiation and $13 \%(2 / 15)$ who received radiation $(\mathrm{p}=1.0)$. However, for reoperations, 1 (7\%) of 15 with GTR+NTR had tumor regrowth, in contrast to $2(29 \%)$ of 7 with STR or less. In the overall cohort, there was a significantly higher tumor regrowth following STR, biopsy, or fenestration (33\%) than GTR+NTR (4\%; $\mathrm{p}=0.02)$. This impact of EOR on tumor regrowth was also uniform across other subgroups of age and radiation (Table 4). Patients with tumor regrowth had significantly higher baseline BMI (median $34 \mathrm{vs} 28 \mathrm{~kg} / \mathrm{m}^{2}$, $\mathrm{p}=0.04$ ) than those with no regrowth had (Fig. 2).

\section{Body Mass Index}

The overall trend in BMI is depicted in Fig. 3. There was a significant increase in median BMI from $28.7 \mathrm{~kg} / \mathrm{m}^{2}$ (IQR $24.6-33.7 \mathrm{~kg} / \mathrm{m}^{2}$ ) at surgery to $34 \mathrm{~kg} / \mathrm{m}^{2}$ (IQR $29.4-$ $\left.39.2 \mathrm{~kg} / \mathrm{m}^{2}\right)$ at $2-5$ years $(\mathrm{p}=0.01)$, which remained stable over 10 years (median $34.8 \mathrm{~kg} / \mathrm{m}^{2}$ ). Following first-time operations, median BMI increased from $27.9 \mathrm{~kg} / \mathrm{m}^{2}$ (IQR $24.8-31.6 \mathrm{~kg} / \mathrm{m}^{2}$ ) to $32.5 \mathrm{~kg} / \mathrm{m}^{2}$ (IQR $28.6-36.3 \mathrm{~kg} / \mathrm{m}^{2}$ ) for 5 years, and then stabilized to $30.3 \mathrm{~kg} / \mathrm{m}^{2}$ (IQR $29.9-31.0$ $\mathrm{kg} / \mathrm{m}^{2}$ ) at 10 years. Following reoperation, median BMI increased from $30.6 \mathrm{~kg} / \mathrm{m}^{2}$ (IQR $24.6-34.8 \mathrm{~kg} / \mathrm{m}^{2}$ ) to 35.0 

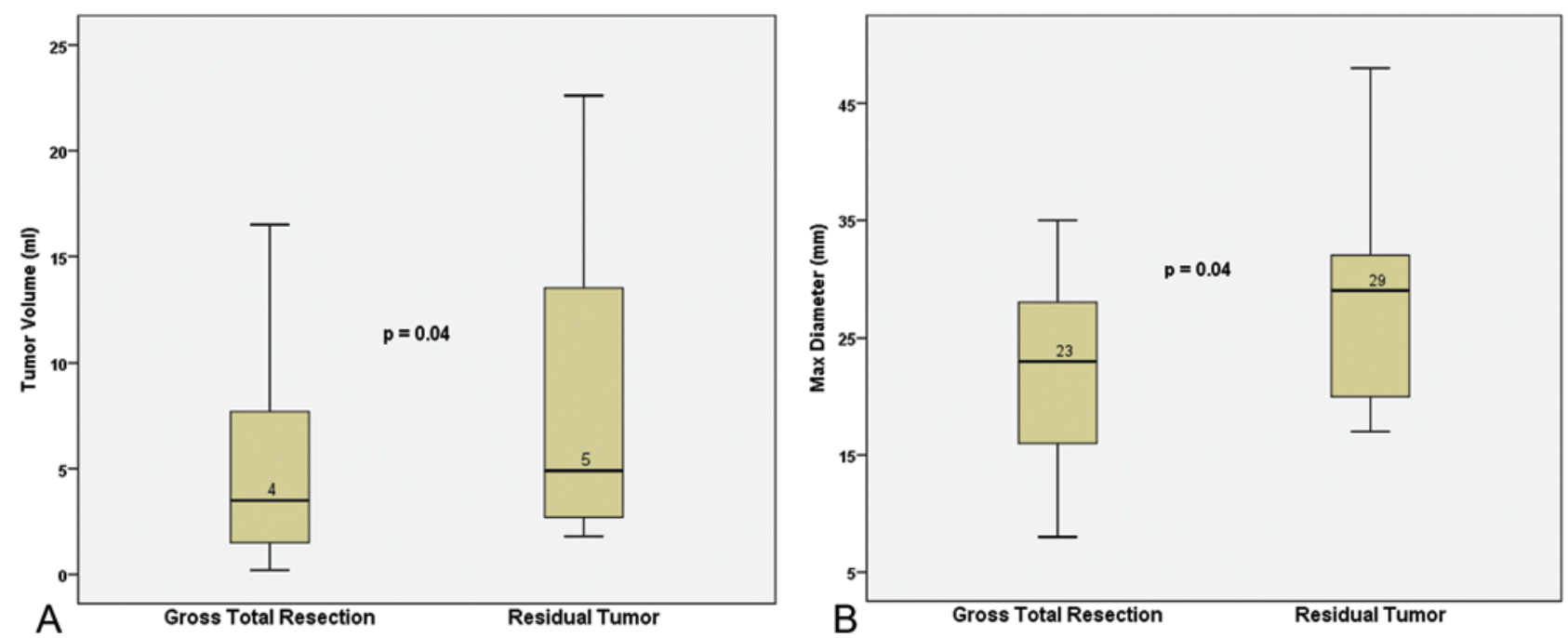

FIG. 1. GTR in relation to $(\mathbf{A})$ tumor volume $(\mathrm{ml})$ and $(\mathbf{B})$ maximum diameter $(\mathrm{mm})$. Figure is available in color online only.

$\mathrm{kg} / \mathrm{m}^{2}\left(\mathrm{IQR} 30.7-39.2 \mathrm{~kg} / \mathrm{m}^{2}\right)$ over 5 years and then further increased to $43.3 \mathrm{~kg} / \mathrm{m}^{2}$ (IQR $39.1-47.4 \mathrm{~kg} / \mathrm{m}^{2}$ ) at 10 years (Fig. 3). There was no statistically significant difference in the overall increase in BMI following first-time surgery compared with reoperation $(p=0.69)$. An increase in BMI was not significantly different following STR compared with GTR+NTR or following radiation compared with no radiation.

TABLE 3. Impact of various factors on vision and pituitary function

\begin{tabular}{|c|c|c|c|c|c|c|c|}
\hline \multirow[b]{2}{*}{ Category } & \multicolumn{3}{|c|}{ Visual Outcome in Those w/ Deficits (\%) } & \multicolumn{4}{|c|}{ Endocrine Outcome in Those w/ Some Pituitary Function (\%) } \\
\hline & Improved & Unchanged & p Value & Additional Anterior Pituitary Hypofunction* & $\mathrm{p}$ Value & New DI† & $\mathrm{p}$ Value \\
\hline Total & $36 / 47$ & $11 / 47$ & & $21 / 48$ & & $23 / 42$ & \\
\hline Age & & & 0.66 & & 0.68 & & 0.67 \\
\hline Child & $5(71)$ & $2(29)$ & & $4 / 7(57)$ & & $4 / 6(67)$ & \\
\hline Adult & $31(78)$ & $9(22)$ & & $17 / 41(42)$ & & $19 / 36(53)$ & \\
\hline Surgery & & & 0.56 & & 0.08 & & 0.08 \\
\hline Primary & $20(80)$ & $5(20)$ & & $18 / 35(51)$ & & $15 / 32(47)$ & \\
\hline Reop & $16(73)$ & $6(27)$ & & $3 / 13(23)$ & & $8 / 10(80)$ & \\
\hline EOR & & & 1.00 & & 0.73 & & 0.71 \\
\hline NTR/total & $27(75)$ & $9(25)$ & & $16 / 38(42)$ & & $19 / 33(58)$ & \\
\hline STR/ biopsy/fenestrations & $9(82)$ & $2(18)$ & & $5 / 10(50)$ & & $4 / 9(44)$ & \\
\hline Radiation & & & 0.31 & & 0.47 & & 0.73 \\
\hline No & $23(82)$ & $5(18)$ & & $16 / 34(47)$ & & $16 / 31(52)$ & \\
\hline Yes & $13(68)$ & $6(32)$ & & $5 / 14(36)$ & & $7 / 11(64)$ & \\
\hline Serum PRL & & & 0.66 & & 0.17 & & 0.29 \\
\hline Normal & $28(74)$ & $10(26)$ & & $14 / 37(38)$ & & $15 / 31(48)$ & \\
\hline High & $8(89)$ & $1(11)$ & & $7 / 11(64)$ & & 8/11 (73) & \\
\hline Hydrocephalus & & & 0.66 & & 0.06 & & 0.68 \\
\hline No & $29(74)$ & $10(26)$ & & $20 / 40(50)$ & & $20 / 35(57)$ & \\
\hline Yes & $7(88)$ & $1(12)$ & & $1 / 8(13)$ & & $3 / 7(43)$ & \\
\hline Third ventricle involvment & & & 0.46 & & 0.27 & & 0.08 \\
\hline No & $12(86)$ & $2(14)$ & & 4/13 (31) & & $4 / 12(33)$ & \\
\hline Yes & $24(73)$ & $9(27)$ & & $17 / 35(49)$ & & $19 / 30(63)$ & \\
\hline Retroinfundibular extension & & & 0.66 & & 0.44 & & 0.68 \\
\hline No & $8(89)$ & $1(11)$ & & $2 / 8(25)$ & & $3 / 7(43)$ & \\
\hline Yes & $28(74)$ & $10(26)$ & & $19 / 40(48)$ & & $20 / 35(57)$ & \\
\hline
\end{tabular}

* Prior panhypopituitarism excluded.

$\dagger$ Prior DI excluded. 
TABLE 4. Impact of various factors on tumor regrowth

\begin{tabular}{|c|c|c|c|c|c|}
\hline \multirow[b]{2}{*}{ Subgroups } & \multicolumn{2}{|c|}{ Subgroups } & \multicolumn{3}{|c|}{ EOR } \\
\hline & $\begin{array}{l}\text { Overall Tumor } \\
\text { Regrowth (\%) }\end{array}$ & $\begin{array}{c}\mathrm{p} \\
\text { value }^{*}\end{array}$ & $\begin{array}{l}\text { GTR/ } \\
\text { NTR }\end{array}$ & $\begin{array}{c}\text { STR/Biopsy/ } \\
\text { Fenestration } \\
\quad(\%)\end{array}$ & $\begin{array}{c}p \\
\text { Value }\end{array}$ \\
\hline Total & 6/57 (11) & & 2/45 (4) & 4/12 (33) & $0.02^{*}$ \\
\hline Age & & 1.00 & & & $0.77 \dagger$ \\
\hline Children & 1/9 (11) & & $0 / 4(0)$ & $1 / 5(20)$ & \\
\hline Adults & $5 / 48(10)$ & & 2/41 (5) & 3/7 (43) & \\
\hline Surgery & & 0.67 & & & $0.51 \dagger$ \\
\hline Primary & $3 / 35(9)$ & & 1/30 (3) & $2 / 5(40)$ & \\
\hline Reop & $3 / 22$ (14) & & $1 / 15(7)$ & 2/7 (29) & \\
\hline Radiation & & 0.39 & & & $0.08 \dagger$ \\
\hline No & $3 / 38$ (8) & & 1/35 (3) & 2/3 (67) & \\
\hline Yes & $3 / 19(16)$ & & $1 / 10(10)$ & $2 / 9(22)$ & \\
\hline
\end{tabular}

\section{Quality of Life}

QOL could be assessed for 38 patients at different time intervals. Preoperative QOL was slightly lower for reoperations (ASBS-Q $=105$ ) compared with first operations (ASBS- $\mathrm{Q}=112.5)$, but this was not significant $(\mathrm{p}=0.52)$. There was an overall improvement in median ASBS-Q scores between pre- and postoperative measurements for both first-time and reoperations. There was an initial decrease following surgery, which improved gradually and crossed the baseline level between 3 and 6 months, reaching significance between 6 and 12 months $(p=0.03$; Fig. 4). There was no significant difference in the improvement in QOL at 6-12 months between first and reoperative endonasal surgery ( $\mathrm{p}=0.15$; Fig. 5 ). EOR had a nonsignificant impact on change in QOL. Although GTR or NTR resulted in QOL improvement, there was worsening in median ASBS-Q QOL following STR ( $p=0.8$; Fig. 5).

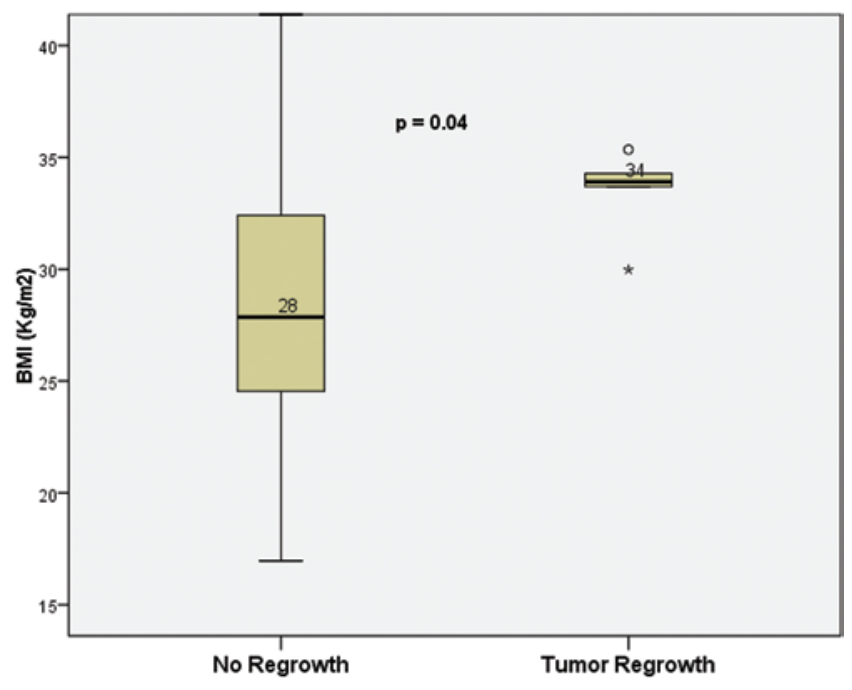

FIG. 2. Baseline BMI $\left(\mathrm{kg} / \mathrm{m}^{2}\right)$ versus tumor regrowth. The open circle represents mild outliers and the star represents extreme outliers. Figure is available in color online only.
Among the 6 different domains of ASBS-Q QOL, there was significant improvement in performance $(p=0.03)$ and vitality $(\mathrm{p}=0.01)$ at $6-12$ months following surgery (Fig. 6). While improvement following primary surgery was noted in all domains except specific symptoms, reoperation resulted in improvement in only 2 of the 6 domains (performance and vitality).

\section{Multivariate Analyses}

Multivariate analysis was performed using binary logistic regression and a general linear model on various outcome parameters after adjusting for age, type of surgery, prior radiation, baseline BMI, prior DI, elevated PRL, tumor volume, and EOR, as per the univariate analysis $($ Table 5). Prior radiation $(\mathrm{p}=0.02)$ and high tumor volume $(\mathrm{p}=0.02)$ had a significant independent association with lower EOR, while lower EOR $(\mathrm{p}=0.04)$ had a significant independent association with tumor regrowth. Reoperation had a nonsignificant independent association with endocrine worsening and increase in BMI $(\mathrm{p}=0.07)$. The improvement in QOL following surgery was overall homogeneous with no significant independent factor.

\section{Discussion}

The major finding of this report is that reoperation using the endonasal endoscopic approach at an experienced center results in similar EOR with no increase in rate of complications other than DI. In general, patients with STR following their initial surgery are offered radiation therapy, and radiation has been shown to decrease recurrence rates. However, radiation is not uniformly effective, and patients who have undergone radiation treatment after prior STR have lower rates of resection on reoperation. This finding implies a possible change in the algorithm for managing craniopharyngiomas. Namely, when the goal of surgery is GTR but GTR is not achieved during the first operation, the patient should be offered a reoperative attempt at GTR using the endonasal endoscopic approach at an experienced center. Radiation should be used only if this second attempt at GTR is unsuccessful.

Regardless of whether it is a first operation or a reoperation, the risks associated with craniopharyngioma surgery, based on craniopharyngiomas' consistency and location adjacent to critical neurovascular structures, have made them highly challenging tumors for neurosurgical removal. ${ }^{5,25,56}$ Rates of GTR with a craniotomy range from $18 \%$ to $84 \%$ in different series, ${ }^{25}$ with a combined rate of $48 \%{ }^{31}$ Experience of the surgeon has also been noted to impact outcome ${ }^{49}$ Recurrences occur anywhere from $0 \%$ to $62 \%$ at 10 years, even after apparent GTR. ${ }^{25,44}$ Alternative treatment strategies have been suggested such as cyst fenestration and radiation, ${ }^{53}$ as well as administration of intracystic chemotherapy ${ }^{3}$ or liquid radiation therapy. ${ }^{23,28}$ However, progression-free survival with such a strategy is only $46 \%{ }^{40}$ Management of residual/recurrent tumors is even more challenging, and reported rates of GTR with a craniotomy are often less than $25 \%$ with further increased perioperative mortality ranging from $11 \%$ to $24 \%$, due to the scarring in the operative area..$^{15,24,25,51}$ As an alternative to reoperation, radiation therapy has been suggested for 

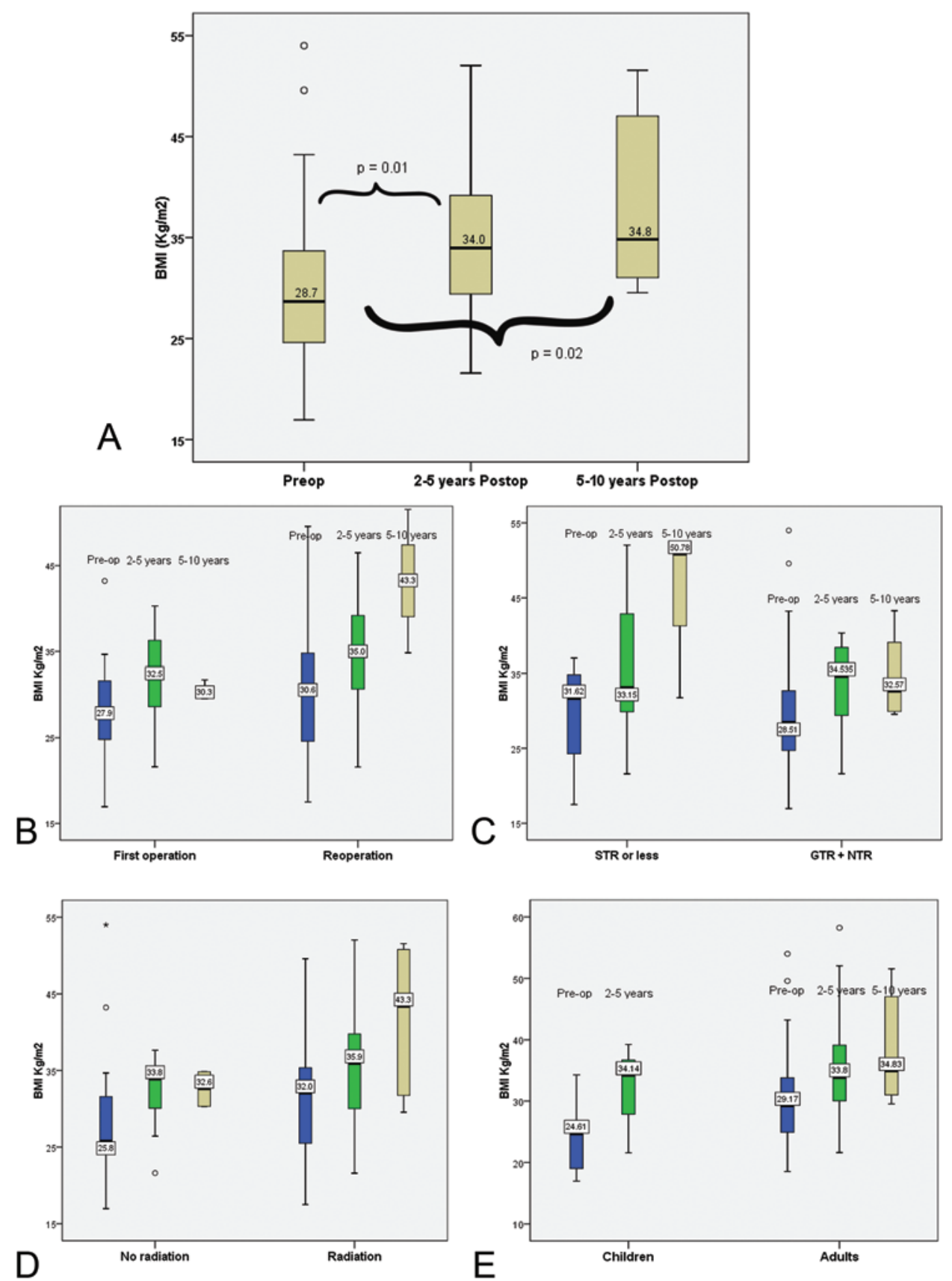

FIG. 3. Graphs showing changes in BMI following endonasal surgery overall (A), and in relation to reoperation (B), EOR (C), radiation (D), and age (E). The open circles represent mild outliers and the star represents extreme outliers. Figure is available in color online only.

recurrent tumors. ${ }^{19,25}$ However, control rates for radiation therapy for recurrent tumors can be low and may require multiple treatments with significant morbidity, particularly in children. ${ }^{25,30}$ Re-recurrence rates of tumors after radiosurgery are as high as $45 \%$ at 4 years. ${ }^{35}$

The extended endonasal endoscopic transsphenoidal approach has been increasingly used to manage craniopharyngiomas based on the improved view of the pituitary gland, stalk, undersurface of the chiasm, and hypothalamus. ${ }^{5-7,27,31-33}$ Several reports have shown comparable or improved EOR for first operations with comparable or fewer complications compared with a craniotomy. ${ }^{17,21,31,44}$ However, there are few reports on endonasal surgery for recurrent craniopharyngiomas (Table 6). In this paper, we show that surgical results for reoperative endonasal surgery for recurrent tumors is comparable to the first operation, regardless of whether the prior surgery was completed using a craniotomy, transsphenoidal approach, or cyst fenestration. Prior radiation therapy, however, appeared to decrease the extent of resection. The basis for our success with reoperation is founded on a few surgical principles. First, the endonasal approach was often a new route and so 


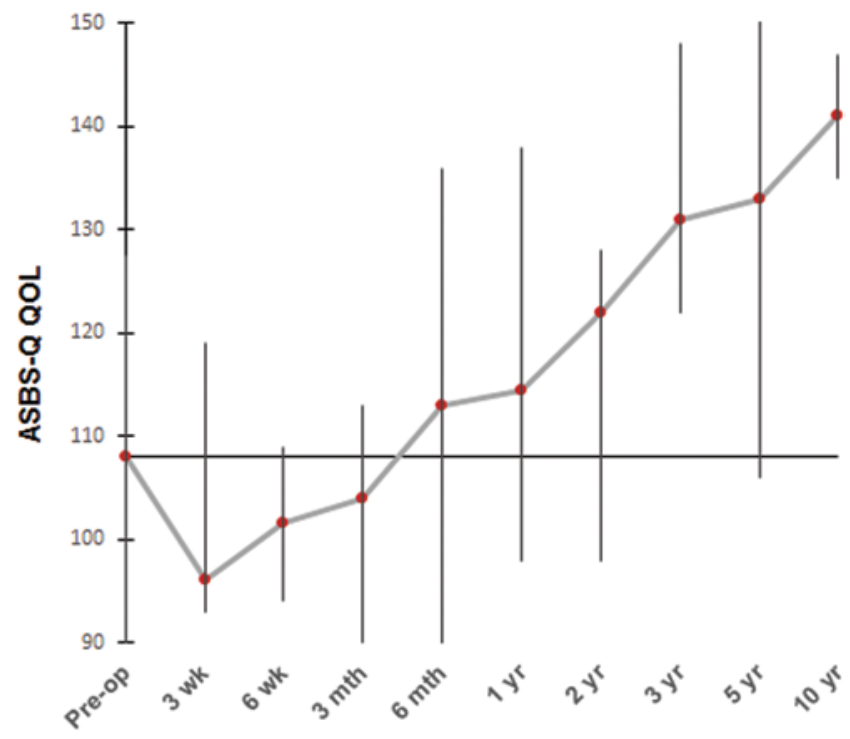

FIG. 4. Overall trend in ASBS-Q QOL following endonasal surgery. Figure is available in color online only.

the scarring encountered was minimal as compared with a reoperative craniotomy after prior craniotomy. Moreover, the visualization of the undersurface of the chiasm and third ventricle are superior using the endonasal endoscopic approach compared with the transcranial approach, and the field of view of the endoscope is wider than that of the microscope. These areas are the most difficult to remove surgically and the endonasal approach offers an advantage for seeing and precisely manipulating this area. Clearly, patients chosen for endonasal surgery do not have significant lateral extent into the middle or posterior fossa, areas that are not well visualized by the endonasal approach.

Our results are slightly better than reports in the few prior papers on endonasal reoperation for recurrent craniopharyngiomas (Table 6). Previously published GTR rates ranged from $29 \%$ to $83 \%$ with an average endonasal endoscopic GTR rate of $57 \% .{ }^{5,29,32}$ Overall, the GTR rates for endonasal endoscopic reoperations are much better than transcranial microscopic $(0 \%-56 \%)^{4,15,24,29,51,54,57}$ or transsphenoidal microscopic $(6 \%-53 \%)^{15,20,34}$ reoperations. Hence, the prior published data support our contention that extended endonasal endoscopic reoperations result in higher rates of GTR compared with other operative corridors or techniques. This is true for prior transsphenoidal surgery as well as prior craniotomy and so is not merely a result of a new unscarred approach corridor but more likely from the improved view of areas of likely scarring and recurrence such as the undersurface of the chiasm and hypothalamus. Moreover, no CSF leaks occurred in our study, compared with $12 \%-14 \%$ reported in the literature. ${ }^{6,32}$ We attribute this low leak rate to our use of the "gasket seal" combined with a nasoseptal flap and lumbar drainage. . $^{216,37,41,45}$

Radiation is often used in subtotally resected tumors to control regrowth. For this reason, it is difficult to differentiate the impact of radiation on reoperation, because the majority of patients who require reoperation have already undergone radiation. Nevertheless, our finding of decreased EOR following radiation is also borne out in other publications. Transcranial reoperations following radiation reported GTR rates of just $19 \%-25 \%{ }^{14,39}$ Elliott et al..$^{14}$ noted that prior radiation lowered the extent of resection in transcranial reoperations. Cavallo et al. ${ }^{6}$ reported that GTR decreased from 50\% to $25 \%$ after prior radiation. This raises the intriguing possibility that an endonasal reoperation for recurrent or residual tumor may actually be preferable to radiation therapy in controlling disease if this approach has not already been performed in experienced hands, assuming the surgeon determines that a GTR or NTR can be achieved. Although rates of endocrinopathy clearly increase after radiation therapy, radiation therapy may also negatively impact pituitary function, although not as acutely as surgery (Table 6). New DI following reoperation for craniopharyngiomas has been reported, ranging from $14 \%$ to $100 \%$ in various series, ${ }^{5,14,20,32}$ in comparison with $31 \%$ following radiation..$^{48}$ New ante-
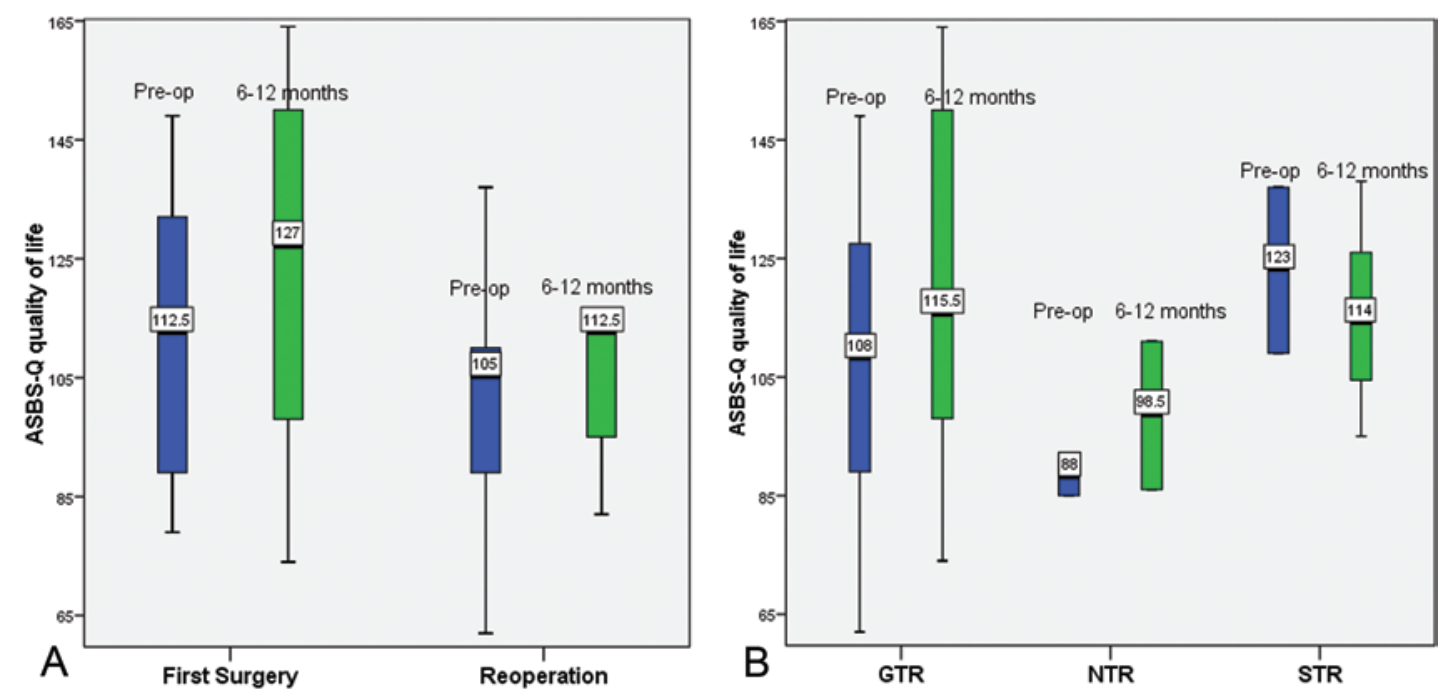

FIG. 5. Change in ASBS-Q QOL in relation to reoperation (A) and EOR (B). Figure is available in color online only. 

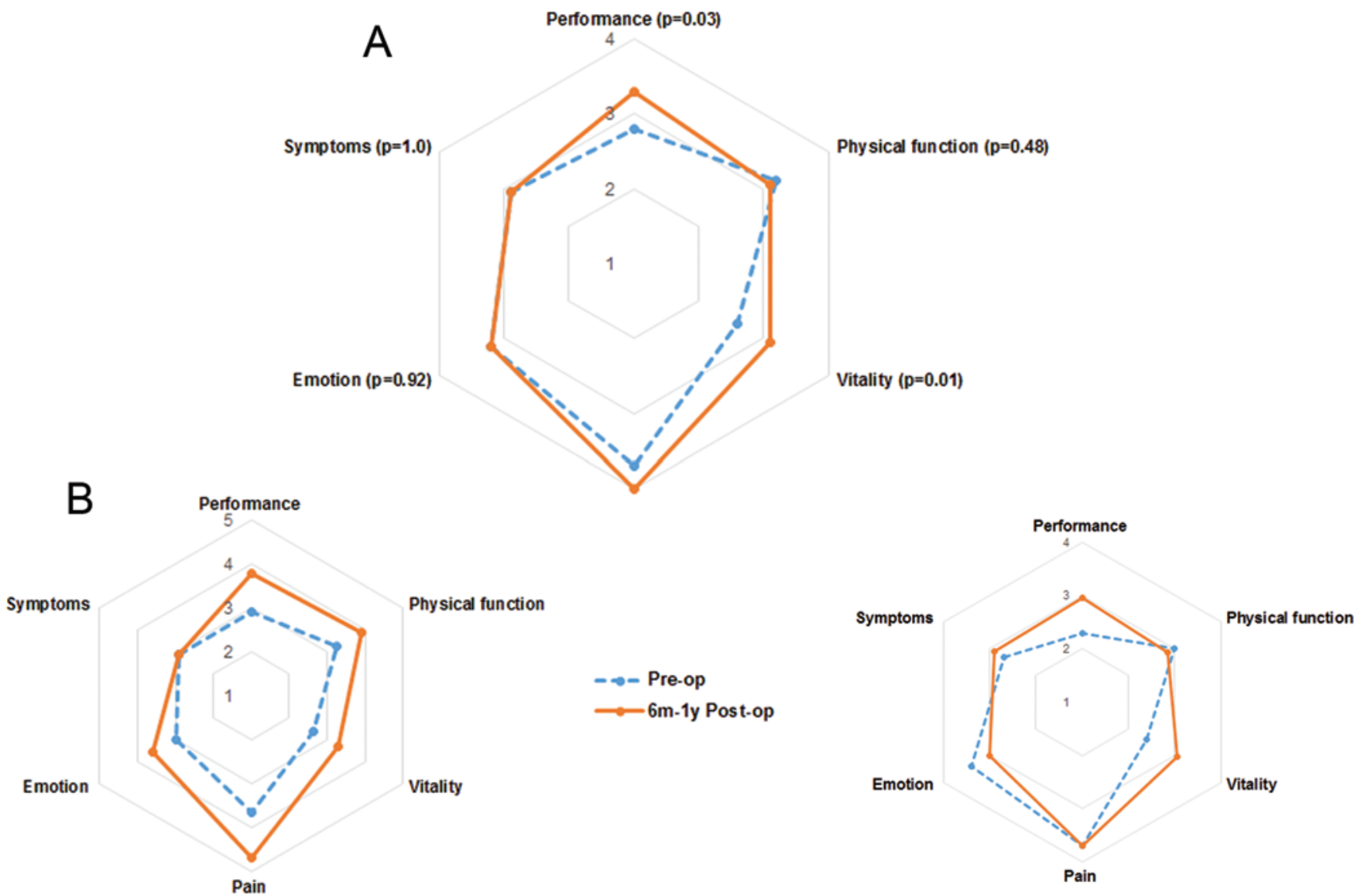

FIG. 6. Changes in different domains of ASBS-Q QOL overall (A), first surgery (B), and reoperation (C). $m=$ month; $y=$ year. Figure is available in color online only.

rior pituitary hypofunction, however, appears to be similar following reoperation or radiation. $., 20,22,32,51$

In spite of the presumed scar between the tumor and the optic chiasm and nerves, visual improvement after reoperation was quite high, as has also been reported in other endonasal endoscopic studies (Table 6). ${ }^{5,32}$ The visual improvement in these endonasal reoperation series appears to be better than transcranial reoperations $(33 \%-64 \%)^{14,15}$ or salvage radiation $(11 \%-36 \%){ }^{35,48}$ Radiation, however, tended to decrease the rate of visual improvement, as is also demonstrated in other studies.22,25,30,39 Once again, this finding implies that patients with a recurrent craniopharyngioma and salvageable but waning vision might be better served with an extended endonasal endoscopic reoperation compared with radiation therapy to maximize visual improvement. Improved visual outcome after endonasal surgery compared with other approaches also mirrors findings in first-time operations, where visual improvement is highest following endonasal surgery. ${ }^{31}$

Our tumor re-recurrence rate of $14 \%$ at a median fol-

TABLE 5. Multivariate analysis*

\begin{tabular}{|c|c|c|c|c|c|c|c|c|c|c|}
\hline \multirow[b]{2}{*}{ Variable } & \multicolumn{2}{|c|}{ EOR } & \multicolumn{2}{|c|}{ Tumor Regrowth } & \multicolumn{2}{|c|}{ Endocrine Outcome } & \multicolumn{2}{|c|}{ BMI Increase } & \multicolumn{2}{|c|}{ QOL Increase } \\
\hline & $p$ Value & Adj OR & p Value & Adj OR & p Value & Adj OR & p Value & F Value & p Value & F Value \\
\hline Age & 0.22 & 1.03 & 0.68 & 1.02 & 0.64 & 1.02 & 0.73 & 7.87 & 0.32 & 3.34 \\
\hline Reop & 0.94 & 1.1 & 0.22 & 15.42 & 0.07 & 83.33 & 0.07 & 3.73 & 0.32 & 3.38 \\
\hline Radiation & 0.02 & 71.43 & 0.57 & 4.08 & 0.68 & 428 & 0.78 & 12.2 & 0.57 & 1.58 \\
\hline BMI & 0.69 & 1.03 & 0.28 & 1.12 & 0.11 & 1.32 & 0.12 & 2.76 & 0.52 & 1.11 \\
\hline Prior DI & 0.08 & 16.24 & 0.63 & 2.86 & 1.0 & NA & 0.58 & 3.11 & 0.32 & 3.43 \\
\hline High PRL & 0.83 & 1.29 & 1.0 & NA & 0.51 & 3.36 & 0.08 & 3.57 & 0.25 & 5.93 \\
\hline Tumor volume & 0.02 & 1.1 & 0.38 & 1.11 & 0.60 & 1.13 & 0.19 & 1.88 & 0.33 & 3.16 \\
\hline EOR & & & 0.04 & 55.56 & 0.75 & 125 & 0.87 & 35.7 & 0.62 & 2.1 \\
\hline
\end{tabular}

Adj = adjusted; $N A$ = not applicable.

* Boldface type indicates statistical significance. 
TABLE 6. Comparison of our series with literature*

\begin{tabular}{|c|c|c|c|c|c|c|c|c|}
\hline \multirow[b]{2}{*}{ Re-Intervention } & \multirow[b]{2}{*}{ GTR } & \multirow{2}{*}{$\begin{array}{l}\text { 30-Day } \\
\text { Mortality }\end{array}$} & \multirow{2}{*}{$\begin{array}{l}\text { CSF } \\
\text { Leak }\end{array}$} & \multicolumn{2}{|c|}{ Visual Outcome } & \multirow{2}{*}{$\begin{array}{l}\text { New Anterior Pituitary } \\
\text { Hypofunction }\end{array}$} & \multirow{2}{*}{$\begin{array}{l}\text { New } \\
\text { DI }\end{array}$} & \multirow{2}{*}{$\begin{array}{c}\text { Regrowth Rate } \\
4-5 \text { Yrs }\end{array}$} \\
\hline & & & & Improved & Worse & & & \\
\hline \multicolumn{9}{|l|}{ Radiation } \\
\hline Lee et al., 2014 & & & & 11 & 24 & & & 45 \\
\hline Rajan et al., 1993 & & & & 36 & 33 & & 31 & \\
\hline Jose et al., 1992 & & & & & & 78 & & \\
\hline Klimo et al., 2015 & & & & & & & & 19 \\
\hline \multicolumn{9}{|l|}{ Transcranial microscopic } \\
\hline Karavitaki et al., 2005 & 0 & 24 & & & & & & \\
\hline Barua et al., 2003 & 11 & & & & & & & \\
\hline Fahlbusch et al., 1999 & 21 & 11 & & 64 & 19 & & & \\
\hline Van Effenterre \& Boch, 2002 & 25 & & & & & & & \\
\hline Šteňo et al., 2014 & 50 & & & & & 17 & & \\
\hline Yaşargil et al., 1990 & 56 & & & & & & & \\
\hline Elliott et al., 2010 & & & & 33 & 24 & & 89 & 18 \\
\hline Duff et al., 2000 & & & & & & & & 23 \\
\hline \multicolumn{9}{|l|}{ Transsphenoidal microscopic } \\
\hline Laws, 1994 & 6 & & & & & & & 33 \\
\hline Jane et al., 2010 & 36 & & & 60 & 10 & 100 & 100 & 27 \\
\hline Fahlbusch et al., 1999 & 53 & & & 55 & 0 & & & \\
\hline \multicolumn{9}{|l|}{ Endonasal endoscopic } \\
\hline Cavallo et al., 2014 & 62 & & & 73 & 5 & & & \\
\hline Koutourousiou et al., 2013 & 29 & 0 & 12 & & & 60 & 50 & 35 \\
\hline Cavallo et al., 2009 & & 0 & 14 & & & 40 & 14 & 18 \\
\hline Kim et al., 2014 & 83 & & & & & & & \\
\hline Current series & $80 / 55 \dagger$ & 0 & 0 & 73 & 0 & 23 & 80 & 14 \\
\hline
\end{tabular}

low-up of 4 years following endonasal reoperations is comparable to, albeit a bit lower than, that in other surgical series $(18 \%-35 \%)^{5,14,20,32,34}$ and after salvage radiation $(19 \%-45 \%){ }^{30,35} \mathrm{In}$ fact, there was no significant difference in recurrence rate between first-time surgeries and reoperations, which again emphasizes the utility of reoperations for this disease. The critical factor impacting recurrence was EOR. The impact of EOR on recurrence was significant in univariate analysis as well as in multivariate analysis, demonstrating the independent effect of the extent of resection on tumor recurrence, irrespective of whether the resection was a first-time surgery or reoperation. Radiation decreased the rate of recurrence only in tumors that had undergone STR or less in our study, similar to other series. ${ }^{14,25}$ Hence, we recommend reserving radiation only for patients who clearly have residual tumor after surgery as an effective means to reduce the risk of recurrence when surgical options have failed, including endonasal reoperation.

The increase in BMI following surgery for craniopharyngiomas has been reported previously, regardless of the surgical approach. ${ }^{8,25,55}$ We noted the increase in BMI to have a nonsignificant association with reoperation. Gautier et al. and Elliott et al. had noted a similar higher trend in BMI following transcranial reoperation for recurrent tu- mors. ${ }^{14,17}$ Reoperations may put the hypothalamus at more risk, because these tumors clearly had residual tissue after the first operation, and the hypothalamus is a common site of residual tumor, near the ventromedial hypothalamic nuclei that contain the "satiety center." $8,11,25,52,55$ Higher baseline BMI among those with tumor regrowth may be due to prior hypothalamic infiltration with increased residual cell rests giving rise to tumor regrowth or other adipokineinduced mechanisms. ${ }^{8,10,11,55}$

Quality of life generally deteriorates after craniotomy for craniopharyngiomas. Three studies in adults and 1 in children have all shown deterioration in QOL either with, or even without, treatment. ${ }^{9,26,44,58}$ Endonasal endoscopic primary surgery for craniopharyngiomas, on the other hand, has been shown to lead to maintenance of QOL for more than 9 months after surgery. ${ }^{46}$ This current study demonstrates an improvement in QOL after endonasal endoscopic reoperation for craniopharyngioma following a transient decline. The transient decline has also been demonstrated following endonasal endoscopic resection of pituitary adenomas and other skull base tumors as a result of transient sinonasal complaints that improve after 6 weeks. ${ }^{42,43}$ The impact of reoperation on QOL has not been well studied. A possible explanation for such improvements is the fact that patients with recurrent radiated tumors may be quite 
discouraged prior to surgery and express significant improvements in emotional well-being after the tumor is completely removed. The fact that preoperative QOL was lower in patients undergoing reoperations compared with first operations supports this explanation.

In our multivariate analysis, reoperation did not impact EOR or recurrence. Rather, tumor volume and prior radiation impacted the EOR, and EOR impacted tumor regrowth. Together, these data point to an algorithm that favors reoperation over radiation if there is tumor recurrence after a first operation that, in the surgeon's estimation, can be completely resected with an endonasal endoscopic approach. Radiation is clearly helpful at preventing regrowth and in our opinion should be reserved for subtotally resected tumors.

\section{Conclusions}

Endonasal endoscopic transsphenoidal reoperation results in similar EOR, visual outcome, and improvement in QOL as that of first-time operations. Although the rate of DI and increase in BMI are higher for reoperations, there is no increase in other complications. EOR is more impacted by tumor volume and prior radiation. Reoperations should be offered to patients with recurrent craniopharyngiomas and may be preferable to radiation in patients in whom GTR or NTR can be achieved.

\section{References}

1. Amit M, Abergel A, Fliss DM, Gil Z: The clinical importance of quality-of-life scores in patients with skull base tumors: a meta-analysis and review of the literature. Curr Oncol Rep 14:175-181, 2012

2. Banu MA, Kim JH, Shin BJ, Woodworth GF, Anand VK, Schwartz TH: Low-dose intrathecal fluorescein and etiologybased graft choice in endoscopic endonasal closure of CSF leaks. Clin Neurol Neurosurg 116:28-34, 2014

3. Bartels U, Laperriere N, Bouffet E, Drake J: Intracystic therapies for cystic craniopharyngioma in childhood. Front Endocrinol (Lausanne) 3:39, 2012

4. Barua KK, Ehara K, Kohmura E, Tamaki N: Treatment of recurrent craniopharyngiomas. Kobe J Med Sci 49:123-132, 2003

5. Cavallo LM, Frank G, Cappabianca P, Solari D, Mazzatenta D, Villa A, et al: The endoscopic endonasal approach for the management of craniopharyngiomas: a series of 103 patients. J Neurosurg 121:100-113, 2014

6. Cavallo LM, Prevedello DM, Solari D, Gardner PA, Esposito F, Snyderman CH, et al: Extended endoscopic endonasal transsphenoidal approach for residual or recurrent craniopharyngiomas. J Neurosurg 111:578-589, 2009

7. Conger AR, Lucas J, Zada G, Schwartz TH, Cohen-Gadol AA: Endoscopic extended transsphenoidal resection of craniopharyngiomas: nuances of neurosurgical technique. Neurosurg Focus 37(4):E10, 2014

8. de Vile CJ, Grant DB, Hayward RD, Kendall BE, Neville BGR, Stanhope R: Obesity in childhood craniopharyngioma: relation to post-operative hypothalamic damage shown by magnetic resonance imaging. J Clin Endocrinol Metab 81:2734-2737, 1996

9. Dekkers OM, Biermasz NR, Smit JW, Groot LE, Roelfsema F, Romijn JA, et al: Quality of life in treated adult craniopharyngioma patients. Eur J Endocrinol 154:483-489, 2006

10. Dhandapani S, Kapoor A, Gaudihalli S, Dhandapani M, Mukherjee KK, Gupta SK: Study of trends in anthropomet- ric nutritional indices and the impact of adiposity among patients of subarachnoid hemorrhage. Neurol India 63:531536, 2015

11. Dhandapani S, Karthigeyan M, Dhandapani M: Unusual presentation of hyperphagia after surgery for fourth ventricular ependymoma: accessory satiety center or hypothalamic seedlings? Neurol India 61:320-321, 2013

12. Dhandapani S, Negm HM, Cohen S, Anand VK, Schwartz TH: Endonasal endoscopic transsphenoidal resection of tuberculum sella meningioma with anterior cerebral artery encasement. Cureus 7:e311, 2015

13. Duff J, Meyer FB, Ilstrup DM, Laws ER Jr, Schleck CD, Scheithauer BW: Long-term outcomes for surgically resected craniopharyngiomas. Neurosurgery 46:291-305, 2000

14. Elliott RE, Hsieh K, Hochm T, Belitskaya-Levy I, Wisoff J, Wisoff JH: Efficacy and safety of radical resection of primary and recurrent craniopharyngiomas in 86 children. $\mathbf{J}$ Neurosurg Pediatr 5:30-48, 2010

15. Fahlbusch R, Honegger J, Paulus W, Huk W, Buchfelder M: Surgical treatment of craniopharyngiomas: experience with 168 patients. J Neurosurg 90:237-250, 1999

16. Garcia-Navarro V, Anand VK, Schwartz TH: Gasket seal closure for extended endonasal endoscopic skull base surgery: efficacy in a large case series. World Neurosurg 80:563-568, 2013

17. Gautier A, Godbout A, Grosheny C, Tejedor I, Coudert M, Courtillot C, et al: Markers of recurrence and long-term morbidity in craniopharyngioma: a systematic analysis of 171 patients. J Clin Endocrinol Metab 97:1258-1267, 2012

18. Gil Z, Abergel A, Spektor S, Shabtai E, Khafif A, Fliss DM: Development of a cancer-specific anterior skull base qualityof-life questionnaire. J Neurosurg 100:813-819, 2004

19. Harrabi SB, Adeberg S, Welzel T, Rieken S, Habermehl D, Debus J, et al: Long term results after fractionated stereotactic radiotherapy (FSRT) in patients with craniopharyngioma: maximal tumor control with minimal side effects. Radiat Oncol 9:203, 2014

20. Jane JA Jr, Prevedello DM, Alden TD, Laws ER Jr: The transsphenoidal resection of pediatric craniopharyngiomas: a case series. J Neurosurg Pediatr 5:49-60, 2010

21. Jeswani S, Nuño M, Wu A, Bonert V, Carmichael JD, Black $\mathrm{KL}$, et al: Comparative analysis of outcomes following craniotomy and expanded endoscopic endonasal transsphenoidal resection of craniopharyngioma and related tumors: a singleinstitution study. J Neurosurg 11:1-12, 2015

22. Jose CC, Rajan B, Ashley S, Marsh H, Brada M: Radiotherapy for the treatment of recurrent craniopharyngioma. Clin Oncol (R Coll Radiol) 4:287-289, 1992

23. Julow JV: Intracystic irradiation for craniopharyngiomas. Pituitary 16:34-45, 2013

24. Karavitaki N, Brufani C, Warner JT, Adams CB, Richards P, Ansorge O, et al: Craniopharyngiomas in children and adults: systematic analysis of 121 cases with long-term follow-up. Clin Endocrinol (Oxf) 62:397-409, 2005

25. Karavitaki N, Cudlip S, Adams CB, Wass JA: Craniopharyngiomas. Endocr Rev 27:371-397, 2006

26. Kendall-Taylor P, Jönsson PJ, Abs R, Erfurth EM, KoltowskaHäggström M, Price DA, et al: The clinical, metabolic and endocrine features and the quality of life in adults with childhood-onset craniopharyngioma compared with adult-onset craniopharyngioma. Eur J Endocrinol 152:557-567, 2005

27. Kenning TJ, Beahm DD, Farrell CJ, Schaberg MR, Rosen MR, Evans JJ: Endoscopic endonasal craniopharyngioma resection. J Neurosurg 32 Suppl:E5, 2012

28. Kickingereder P, Maarouf M, El Majdoub F, Fuetsch M, Lehrke R, Wirths J, et al: Intracavitary brachytherapy using stereotactically applied phosphorus-32 colloid for treatment of cystic craniopharyngiomas in 53 patients. J Neurooncol 109:365-374, 2012

29. Kim SK, Kim YH, Park CK, Kim DG, Jung HW: Extended 
endoscopic endonasal approach for recurrent or residual adult craniopharyngiomas. Acta Neurochir (Wien) 156:19171922,2014

30. Klimo P Jr, Venable GT, Boop FA, Merchant TE: Recurrent craniopharyngioma after conformal radiation in children and the burden of treatment. J Neurosurg Pediatr 15:499-505, 2015

31. Komotar RJ, Starke RM, Raper DM, Anand VK, Schwartz TH: Endoscopic endonasal compared with microscopic transsphenoidal and open transcranial resection of craniopharyngiomas. World Neurosurg 77:329-341, 2012

32. Koutourousiou M, Gardner PA, Fernandez-Miranda JC, Tyler-Kabara EC, Wang EW, Snyderman CH: Endoscopic endonasal surgery for craniopharyngiomas: surgical outcome in 64 patients. J Neurosurg 119:1194-1207, 2013

33. Laufer I, Anand VK, Schwartz TH: Endoscopic, endonasal extended transsphenoidal, transplanum transtuberculum approach for resection of suprasellar lesions. J Neurosurg 106:400-406, 2007

34. Laws ER Jr: Transsphenoidal removal of craniopharyngioma. Pediatr Neurosurg 21 (Suppl 1):57-63, 1994

35. Lee CC, Yang HC, Chen CJ, Hung YC, Wu HM, Shiau CY, et al: Gamma Knife surgery for craniopharyngioma: report on a 20-year experience. J Neurosurg 121 (Suppl):167-178, 2014

36. Leng LZ, Anand VK, Schwartz TH: Endoscopic management of craniopharyngiomas. Oper Tech Otolaryngol Head Neck Surg 22:215-222, 2011

37. Leng LZ, Brown S, Anand VK, Schwartz TH: "Gasket-seal" watertight closure in minimal-access endoscopic cranial base surgery. Neurosurgery 62 (5 Suppl 2):E342-E343, 2008

38. Leng LZ, Greenfield JP, Souweidane MM, Anand VK, Schwartz TH: Endoscopic, endonasal resection of craniopharyngiomas: analysis of outcome including extent of resection, cerebrospinal fluid leak, return to preoperative productivity, and body mass index. Neurosurgery 70:110-124, 2012

39. Liubinas SV, Munshey AS, Kaye AH: Management of recurrent craniopharyngioma. J Clin Neurosci 18:451-457, 2011

40. Lo AC, Howard AF, Nichol A, Sidhu K, Abdulsatar F, Hasan $\mathrm{H}$, et al: Long-term outcomes and complications in patients with craniopharyngioma: the British Columbia Cancer Agency experience. Int J Radiat Oncol Biol Phys 88:1011-1018, 2014

41. Mascarenhas L, Moshel YA, Bayad F, Szentirmai O, Salek AA, Leng LZ, et al: The transplanum transtuberculum approaches for suprasellar and sellar-suprasellar lesions: avoidance of cerebrospinal fluid leak and lessons learned. World Neurosurg 82:186-195, 2014

42. McCoul ED, Anand VK, Schwartz TH: Improvements in site-specific quality of life 6 months after endoscopic anterior skull base surgery: a prospective study. J Neurosurg 117:498-506, 2012

43. McCoul ED, Bedrosian JC, Akselrod O, Anand VK, Schwartz TH: Preservation of multidimensional quality of life after endoscopic pituitary adenoma resection. J Neurosurg 123:813-820, 2015

44. Mortini P, Losa M, Pozzobon G, Barzaghi R, Riva M, Acerno $\mathrm{S}$, et al: Neurosurgical treatment of craniopharyngioma in adults and children: early and long-term results in a large case series. J Neurosurg 114:1350-1359, 2011

45. Patel KS, Komotar RJ, Szentirmai O, Moussazadeh N, Raper DM, Starke RM, et al: Case-specific protocol to reduce cerebrospinal fluid leakage after endonasal endoscopic surgery. J Neurosurg 119:661-668, 2013

46. Patel KS, Raza SM, McCoul ED, Patrona A, Greenfield JP, Souweidane MM, et al: Long-term quality of life after endonasal endoscopic resection of adult craniopharyngiomas. J Neurosurg 123:571-580, 2015

47. Placantonakis DG, Tabaee A, Anand VK, Hiltzik D,
Schwartz TH: Safety of low-dose intrathecal fluorescein in endoscopic cranial base surgery. Neurosurgery 61 (3 Suppl):161-166, 2007

48. Rajan B, Ashley S, Gorman C, Jose CC, Horwich A, Bloom HJ, et al: Craniopharyngioma-a long-term results following limited surgery and radiotherapy. Radiother Oncol 26:1-10, 1993

49. Sanford RA: Craniopharyngioma: results of survey of the American Society of Pediatric Neurosurgery. Pediatr Neurosurg 21 (Suppl 1):39-43, 1994

50. Schwartz TH, Fraser JF, Brown S, Tabaee A, Kacker A, Anand VK: Endoscopic cranial base surgery: classification of operative approaches. Neurosurgery 62:991-1005, 2008

51. Šteňo J, Bízik I, Šteňo A, Matejčík V: Recurrent craniopharyngiomas in children and adults: long-term recurrence rate and management. Acta Neurochir (Wien) 156:113-122, 2014

52. Sughrue ME, Yang I, Kane AJ, Fang S, Clark AJ, Aranda D, et al: Endocrinologic, neurologic, and visual morbidity after treatment for craniopharyngioma. J Neurooncol 101:463476, 2011

53. Takano S, Akutsu H, Mizumoto M, Yamamoto T, Tsuboi K, Matsumura A: Neuroendoscopy followed by radiotherapy in cystic craniopharyngiomas-a long-term follow-up. World Neurosurg 84:1305-1315, 1315.e1-1315.e2, 2015

54. Van Effenterre R, Boch AL: Craniopharyngioma in adults and children: a study of 122 surgical cases. J Neurosurg 97:3-11, 2002

55. Van Gompel JJ, Nippoldt TB, Higgins DM, Meyer FB: Magnetic resonance imaging-graded hypothalamic compression in surgically treated adult craniopharyngiomas determining postoperative obesity. Neurosurg Focus 28(4):E3, 2010

56. Yang I, Sughrue ME, Rutkowski MJ, Kaur R, Ivan ME, Aranda D, et al: Craniopharyngioma: a comparison of tumor control with various treatment strategies. Neurosurg Focus 28(4):E5, 2010

57. Yaşargil MG, Curcic M, Kis M, Siegenthaler G, Teddy PJ, Roth P: Total removal of craniopharyngiomas. Approaches and long-term results in 144 patients. J Neurosurg 73:3-11, 1990

58. Zada G, Kintz N, Pulido M, Amezcua L: Prevalence of neurobehavioral, social, and emotional dysfunction in patients treated for childhood craniopharyngioma: a systematic literature review. PLoS One 8:e76562, 2013

\section{Disclosures}

The authors report no conflict of interest concerning the materials or methods used in this study or the findings specified in this paper.

\section{Author Contributions}

Conception and design: Schwartz. Acquisition of data: Dhandapani. Analysis and interpretation of data: Dhandapani. Drafting the article: Dhandapani. Critically revising the article: Schwartz. Reviewed submitted version of manuscript: Schwartz, Dhandapani, Singh, Negm, Cohen. Approved the final version of the manuscript on behalf of all authors: Schwartz. Statistical analysis: Dhandapani. Administrative/technical/material support: Schwartz, Souweidane, Greenfield, Anand. Study supervision: Schwartz.

\section{Correspondence}

Theodore H. Schwartz, Department of Neurosurgery, Weill Cornell Medical College, NewYork-Presbyterian Hospital, 525 East 68th St., Box 99, New York, NY 10065. email: schwarh@ med.cornell.edu. 